\title{
Possibilities of Biogas in Urban Context
}

\author{
Srijana Koirala \\ High Tech Engineering Consultancy Pvt. Ltd. \\ Corresponding Email: srijanaeng@gmail.com
}

\begin{abstract}
:
Increasing population and rapid development in the planet earth have resulted in increasing demand of energy sources. Developed countries have adopted renewable sources in their policy for a sustainable future but, developing countries like Nepal are still lagging behind. Petroleum gas is used by all the city dwellers which is imported from neighboring countries and is not sustainable for a long term. Rapid urban growth has brought solid waste management and energy demand as a great challenge. Production of energy through biogas can help in management of bio-degradable waste as well as fulfill energy demands. This paper highlights study of large-scale biogas plant in and outside Nepal and explains how they have helped in managing waste, fulfilling energy demands and made positive impact in the community. This paper also suggests on possibilities of biogas as an alternative energy in developing scenario of Nepal.
\end{abstract}

Keywords: Biogas, Urban Energy Demand, Alternative Energy, Large Scale Biogas Plant, Municipal Solid Waste, Sustainable

\section{Introduction and Background}

Energy is one of the driving forces that determines the development of today's world. It is essential for almost every activity that occurs in this planet. Demand for energy is increasing in an exponential manner along with development, while sources of energy to fulfill them are limited. Most of the sources of energy we use today are non-renewable. For the continuous supply of energy, dependencies on non-renewable sources like fossil fuels, petroleum products need to be discouraged, with development of alternative renewable source of energy. Degree of usage of renewable source of energy greatly depends upon the availability, technological feasibility of those resources' usage in a particular place. Renewable energy such as solar, wind, bio-gas, hydro and geothermal are developed in various places of the world in order to fulfill the energy demand. Due to the fact that excessive use of fossil fuels is degrading the environment, most of the developed countries have adopted the policy of ending their dependency on fossils fuels, and switch towards renewable and hybrid source of energy.

Among the sectors of energy demand, cooking gas can be considered as the primary need of every individual. In the agricultural country like Nepal, most of the energy for cooking purpose was generated from burning of woods, plants, cow dung, etc. in the traditional society. This had made a huge impact in conservation of forest resources as well as an adverse effect in the environment. There are some existing efficient cooking systems using high calorific value solid biomass resources like briquettes and
ICS, which are provided through government or nongovernment projects in rural areas [1]. Nepal has no or very few sources of natural gases, so there is no potential of natural gas to be used fuel, in order to fulfill the energy demand. With the increase in urban population, there is a high consumption of Liquefied petroleum gas (LPG), which is non-renewable source of energy and is imported from neighboring countries.

Nepal is in the stage of rapid development with about $60 \%$ of the urban population. Most of them are residing in urban growth centers. As population density increases, so does the demand of energy and amount of waste production. The challenge of managing the waste is increasing along with increasing demography. In this scenario, bio-gas can be taken as an alternative source if energy as waste production is more in urban areas due to concentration of large number of residents. This paper tries to make some insights on the possibility of biogas energy in urban and sub-urban areas of Nepal.

\section{Objective of the study}

The specific objectives of the study are:

- To know about the production of biogas energy and its advantage over other sources

- To identify the possibility of biogas energy in the present urban context of Nepal.

\section{Methodology}

The research was done on the pragmatic paradigm consisting of mixture of different methods. It used 
literature reviews to understand the reality of the knowledge, in terms of realizing the use and potential of bio-gas energy. Study of the types of energy that are used in Nepal and present scenario of biogas energy in Nepal was done through baselines study assessment. The prerequirements of biogas production in its different scale were studied to have a relative study with urban areas of Nepal. In depth interviews were taken with professionals working in sector of large scale bio-gas production in Nepal and case studies was done in Ramgram Municipality of Nawalparasi district, in order to underpin the feasibility and potential of biogas in other parts of the country. Kathmandu metropolitan city and Gorkha municipality has been taken in the study of composition of waste in urban and rural municipalities, which forms a base for the ontological claim that the research topic makes, on the possibilities of bio-gas in urban context. Finally, analysis of the demand and feasibility was done followed by drawing the conclusion on possibility of biogas in the growing urban and suburbs of Nepal.

\section{Literature review}

\subsection{Raw materials for biogas production}

Biogas energy can be generated from raw materials which are bio degradable. The raw materials that can be used in production of biogas can be agricultural waste, manure, municipal solid waste, plant material, sewage, green waste or food waste. The types of raw materials can be classified as follows:

\section{a) Agricultural Feedstock}

Agricultural feedstock comprises of animal manure, energy crops, algal biomass and crop residues [2].

b) Community-Based Feedstock

Community based feedstock consists of organic fraction of MSW (OFMSW), MSW, sewage sludge, grass clippings/garden waste, food remains and institutional wastes [2].

c) Industrial Feedstock

Industrial feedstock includes food/beverage processing, dairy, starch industry, sugar industry, pharmaceutical industry, cosmetic industry, biochemical industry, pulp and paper and slaughterhouse [2].

\subsection{Process of Biogas production:}

These bio degradable raw materials go through the process of anaerobic digestion by bacteria. The anaerobic digestion takes place in four basic steps:
Table 1: Comparison of items with their yielding capacity [3]

\begin{tabular}{|l|l|l|}
\hline $\begin{array}{l}\text { S. } \\
\text { No. }\end{array}$ & Type of material & $\begin{array}{l}\text { Biogas yield/ ton fresh } \\
\text { matter (Cubic meter) }\end{array}$ \\
\hline 1 & Cattle dung & $55-68$ \\
\hline 2 & Chicken Litter/dung & 126 \\
\hline 3 & Fat & $826-1200$ \\
\hline 4 & Food waste (Disinfected) & 110 \\
\hline 5 & Fruit waste & 74 \\
\hline 6 & Horse manure & 56 \\
\hline 7 & Maize Silage & $200-220$ \\
\hline 8 & Municipal waste & 101.5 \\
\hline 9 & Sewage sludge & 47 \\
\hline
\end{tabular}

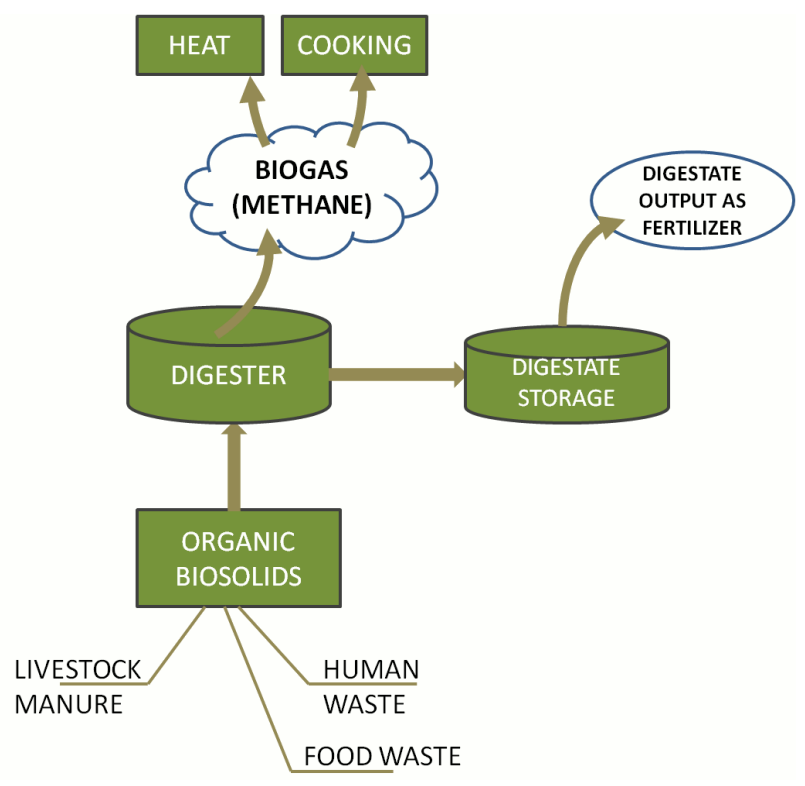

Figure 1: Flow diagram of biogas production [4]

1) Hydrolysis: It includes microbial breakdown of the ingredients such as agricultural, community and industrial based feedstock which are the basic component for generation of biogas. The hydrolysis of these components is done by mixing the above components in a certain proportion with water, so that the $\mathrm{PH}$ of the solution is maintained between 7-7.5. The mixture is mixed by mechanical mean or manually until it turns into a homogeneous mixture [4].

2) Acidogenesis: The homogeneous mixture is then transformed into the products of hydrolysis into short chain volatile acids, ketones, alcohols, hydrogen, and carbon dioxide. 
3) Acetogenesis: During this process, organic acids are converted into acetic acid, ammonia, hydrogen, and carbon dioxide through the microbial action.

4) Methanogenesis: Methanogenesis constitutes the final stage of anaerobic digestion in which methanogens create methane from the final products of acetogenesis as well as from some of the intermediate products from hydrolysis and acidogenesis.

Table 2: Biogas consumption in anaerobic respiration [3]

\begin{tabular}{|l|l|}
\hline Gas & Concentration (\%) \\
\hline $\mathrm{CH}_{4}$ & $50-70$ \\
\hline $\mathrm{CO}_{2}$ & $25-30$ \\
\hline $\mathrm{N}_{2}$ & $0-10$ \\
\hline $\mathrm{H}_{2} \mathrm{O}$ & $0-3$ \\
\hline $\mathrm{O}_{2}$ & $0-3$ \\
\hline $\mathrm{CxHY}_{x}$ & $0-1$ \\
\hline $\mathrm{NH}_{3}$ & $0-0.5$ \\
\hline $\mathrm{R}_{2} \mathrm{SiO}$ & $0-50 \mathrm{mg} / \mathrm{m}^{3}$ \\
\hline
\end{tabular}

\subsection{Advantages of Biogas production:}

The advantages of bio gas are:

- Biogas is eco-friendly.

- Biogas generation reduces soil and water pollution.

- Biogas generation produces organic fertilizer.

- It's a simple and low-cost technology that encourages a circular economy.

- Healthy cooking alternative for developing areas.

- Little technological advancement.

In 2013, it was decided that the Alternative Energy Promotion Centre (AEPC) and the Nepal Energy Efficiency Program (NEEP) will prepare a Biomass Energy Strategy (BEST). The Strategy was ready for implementation in 2014.

The specific objectives of the baseline study assignment were:

- To provide a comprehensive overview on the baseline situation of the bio energy related sectors with respect to its diversity of supply sources and end users

- To analyze major trends over time from earlier studies and their implications in the sector of Nepal

- To analyze institutional responsibilities and challenges in the management of the BE sector;

- To estimate the potential of savings and conservation of biomass resource through the adoption of more efficient technologies
- To identify possible strategic interventions to improve the productivity and labor efficient access to sustainable biomass energy sources and to improve the adoption and usage of efficient bio energy technologies in urban areas

The base line study assignment tried cover a wide range of situations in both the supply and demand side of all relevant sectors in Nepal.

\section{Case studies}

\subsection{International case study of Sweden}

The Swedish 282 biogas plants produced altogether $1,9 \mathrm{TWh}$ biogas in 2015. $63 \%$ of the production was upgraded to bio-methane and used as vehicle fuel. $20 \%$ of the production was used for heating, $3 \%$ was used as electricity and $2 \%$ in industry. Sweden has ambitious targets to have a fossil fuel independent transport sector in 2030 and to become a fossil fuel free country in 2050 . More than $70 \%$ of the methane used as vehicle fuel is biomethane and less than $30 \%$ natural gas. Also, the Swedish Government has decided that by 2018 at least $50 \%$ of the food waste from households, shops and restaurants shall be sorted out and treated biologically in order to re-utilize the nutrients. [5]

Sweden's energy usage is divided into three sectors: housing and services, industry, and transport and is used in three different ways: to produce heating, electricity and vehicle fuels. Increased bio fuel usage is the main reason why Sweden has managed to decrease greenhouse gas emissions by $25 \%$ between 1990 and 2014 [6] .

In order to accomplish one of the Swedish environmental goals, good built environment, a target regarding waste is set to biologically treat $35 \%$ of the organic residues coming from households, restaurants and canteens by 2010. If by-products from the meat and the dairy industry, such as slaughterhouse waste or manure, are used in the biogas production, there is in many cases an obligation for hygienisation of these materials, according to the animal by-product ordinance. The material is hygienised by heating up to $70^{\circ} \mathrm{C}$ for one hour, and the particle size must be less than $12 \mathrm{~mm}$. Digestion of manure from the own farm, and possibly from some farms close by, is exempted from this obligation, as well as digestion of meat residues from the food industry. [6]

Even though Nepal is not in stage of meeting the achievements made by Sweden in the sector of bio gas energy, the study can be discussed under the feasibility 
and scope of bio gas in fulfill energy demand in various sector of a country.

Bio gas has been used in Sweden for vehicular fuel and heating purpose, while it has only been limited in household level cooking in Nepal. The study can be taken as an example in context of country like Nepal, to explore the wide range of use of bio gas.

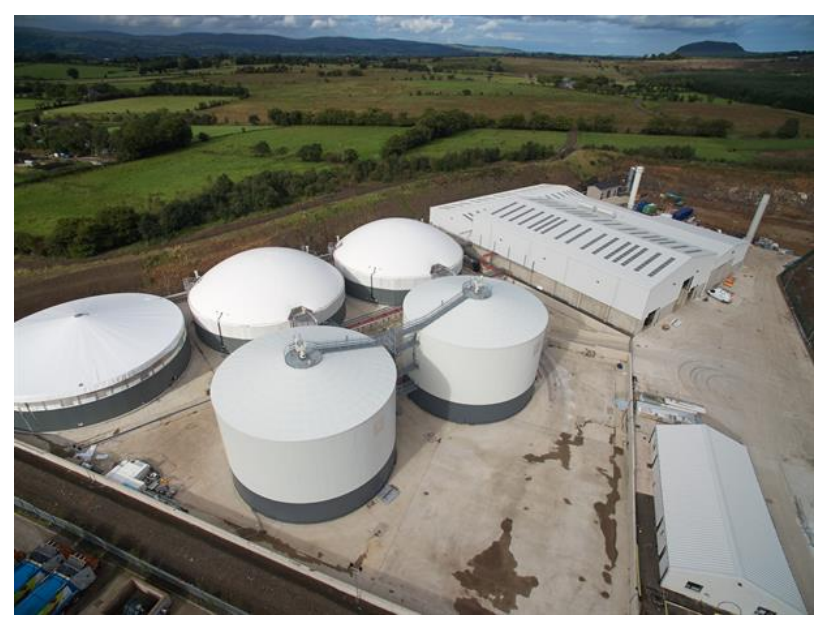

Figure 2: Biogas plant in Sweden [5]

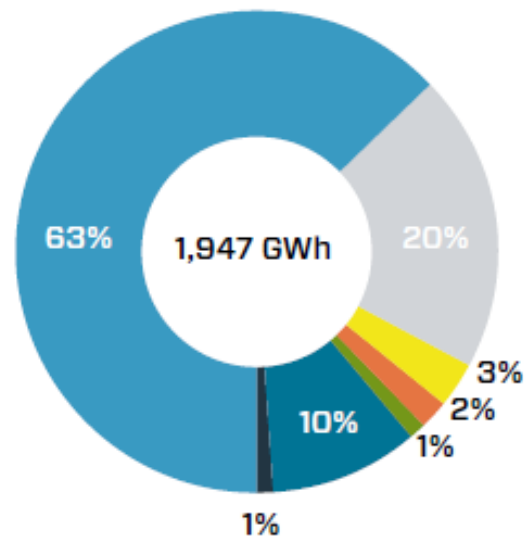

Vehicle fuel

Heat

Electricity

Industrial consumption

Other

Flaring

No data

Figure 3: Biogas consumption, Sweden 2015 [5]

\subsection{National case studies (NV power and fertilizers Pvt. ltd., Ramgram, Nepal)}

In Nepal, over 300,000 household scale biogas plants have been built. From 1992 until 2012, the plants were subsidized under the Biogas Support Program (BSP) and since 2012 under the National Rural Renewable Energy
Program (NRREP) [7]. Even though, the technology is not new in context of Nepal, production of biogas energy is found to be limited in a small household scale rather than promotion in a large scale production and distribution. There are certain initiatives done in Kavre, Pokhara and Nawalparasi for commercial production. Detail case studies and deep interviews were taken to the director of $\mathrm{NV}$ power and fertilizers pvt. Ltd in Ramgarm municipality, Nawalparasi district of Nepal.

The commencement of biogas production in large scale was initiated in 2016 with an investment of 2.2 million dollar and capacity of 4000 cubic meter of digester tank for the production of biogas.

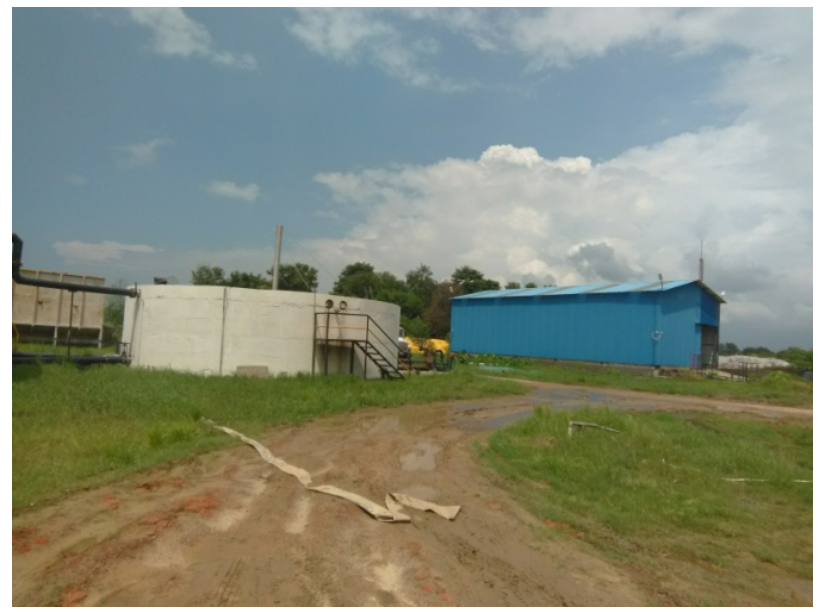

Figure 4: Biogas plant in Ramgram Municipality

The ratios of components that were used as a raw material for the production of biogas are:
a. Chicken litters (6 tons)
b. sugarcane by products ( 4 tons)
c. cow dung (4 tons)
d. water (used in ratio of 1:1 with other components)
e. These materials of 36 ton per day are mixed resulting 1500 cubic meter of solution, from which $16 \%$ is available as fertilizer each day.

This mixture was mixed mechanically until each and every piece were broken down into homogeneous mixture and then fed into the digester. The digester, a large circular container with RCC construction, where the mixture goes through anaerobic process in absence of oxygen, was in controlled temperature and pressure. The temperature was maintained in between 34-38 degree Celsius, with the help of control of temperature of water. Even in case of cold winter, where the outer temperature is not suitable for the anaerobic digestion by bacteria, the wall of digester were fit with coil containing heating affect, where hot water was supplied throughout the pipe in order to maintain the temperature inside the digester. Similarly, the covering of 
digester was made up of flexible material which could be adjusted with the help of outer pump in order to maintain the pressure inside the digester.

The gases from digester comprised about $45-50 \%$ of methane gas, along with $\mathrm{H}_{2} \mathrm{~S}$ and $\mathrm{CO}_{2}$. The gas is then passed through $\mathrm{H}_{2} \mathrm{~S}$ scrubber, which constitutes of fills containing bacteria that eat $\mathrm{H}_{2} \mathrm{~S}$. The $\mathrm{CO}_{2}$ gas is released in the atmosphere. The final end product of biogas contains $94-95 \%$ of methane gas. The methane gas is then passed through the compressor with 200 bar compression and filled into the cylinder.

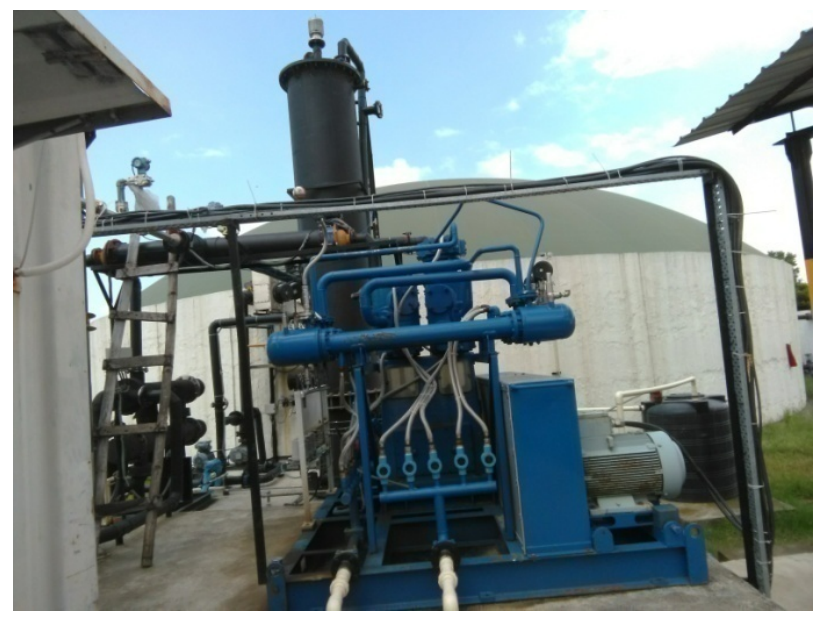

Figure 5: Digester and $\mathrm{H}_{2} \mathrm{~S}$ scrubber

As the gas was filled in very high pressure, the container was made of up pure iron weighing $72-75 \mathrm{~kg}$ per empty cylinder. $11.6 \mathrm{~kg}$ of gas was filled in the container for the distribution. As the cylinder was of high weight, it was found that the supply to individual houses was difficult. Sets of biogas consisting of 2 cylinders each were supplied to hotels and factories.

The ideal features of the biogas plant were [8]:

- The first bio gas plant in Southeast Asia to have 94$95 \%$ of bio methane (as per the company)

- The calorific value of biogas produced was higher (52,000 Jules) than that of LPG (42,000 Jules).

- Being in the gaseous form, $100 \%$ utilization was possible the uniform efficiency throughout the year (even in winter).

- According to the company, consumer will have benefit of $30 \%$ in comparison to cost and waste generated.

- It had also provided employment opportunity to the local people. Currently, 18-20 people are employed in the factory.

\section{Discussion}

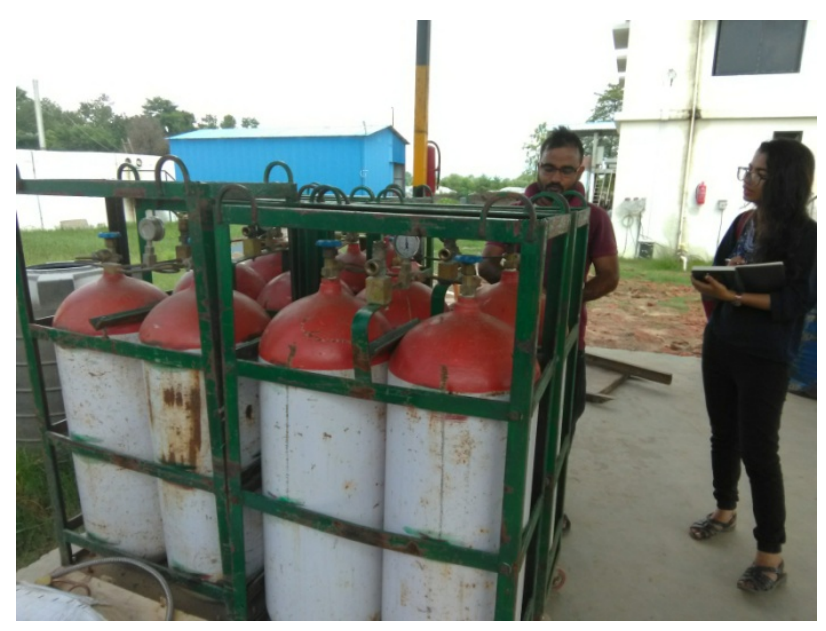

Figure 6: Biogas filled in containers

\subsection{Present energy usage of Nepal}

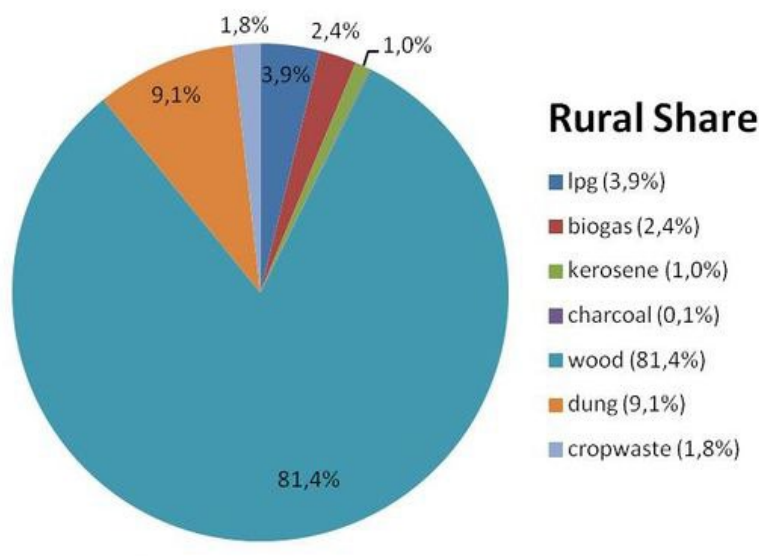

Figure 7: Share of energy in rural areas [9]

Nepal has a lot of energy consumption as compared to its gross domestic product (GDP). Nepal doesn't have any major oil fuel or coal reserve that could be used as energy source. People in urban areas are more inclined to use of gas in cylinder for cooking purpose these days.

In the urban areas, as well as most of the remittanceearning families in rural areas switched to LPG in recent years [10]. Due to lack of reliable source of energy, it has its whole dependency on neighboring countries by importing the gases and petroleum products such as liquefied petroleum gas (LPG) for the cooking and heating purpose, petrol and diesel for fueling the vehicles and air conditioning. The rural share of energy on fossil fuel was $5 \%$ while that of urban areas was over $55 \%$ on 2010 [4]. This data has been increasing in following years, due to easy availability of LPG in urban as well as rural areas. But this trend of use of non-renewable and imported source of energy is unsustainable and increase dependency on neighboring country. 


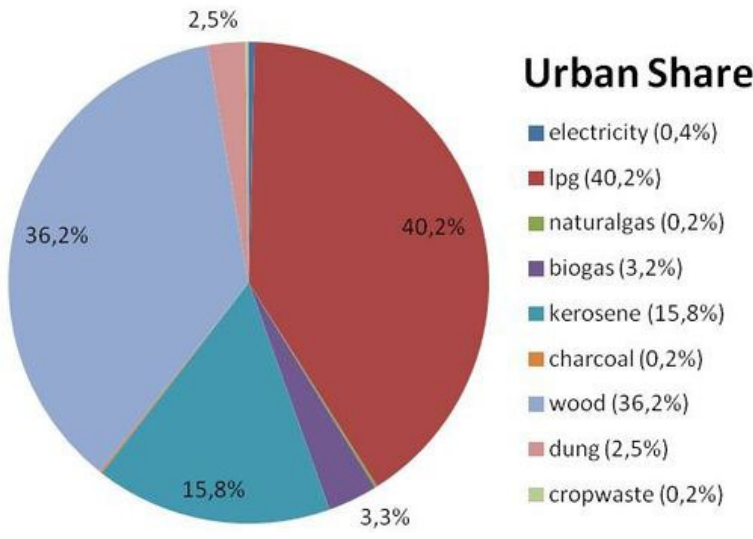

Figure 8: Share of energy in rural areas [9]

\subsection{Import of fossil fuels from foreign country}

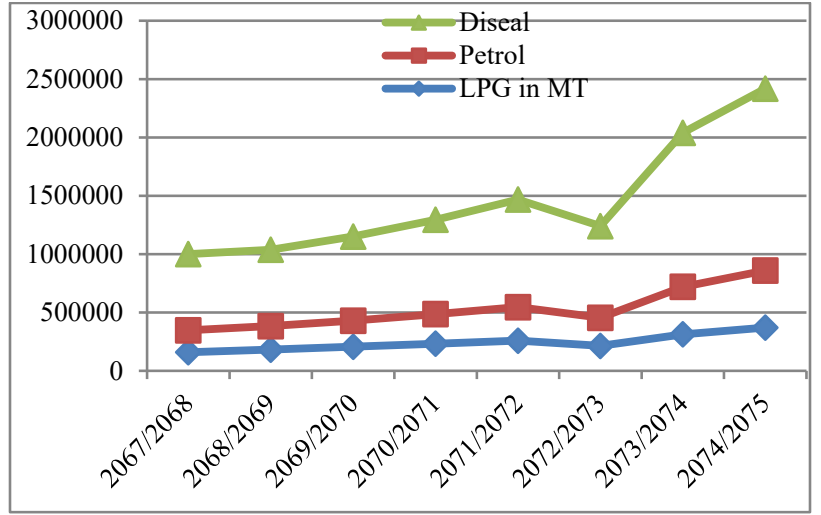

Figure 9: Import of fossil fuels in Nepal [11]

The above graph presents the amount of import of nonrenewable fossil fuels in Nepal for the past eight years, from its neighboring countries. The graph shows the increasing amount of energy demand each year in a rapid manner. This data will go in increasing if necessary, policies and execution is not done on time.

\subsection{An alarming stage}

The data regarding increasing energy usage rapidly, especially of the nonrenewable energy is a serious issue that needs to be taken into consideration. The disadvantages that Nepal is likely to face in coming years due to dependency on fossil fuels are:

a. It is dependent on neighboring country due to lack of reliable source of fossil fuel in the nation. Over $15 \%$ of energy consumption in Nepal is from fossil fuels and is increasing with development. [12]

b. Nepal's reliance on imported fuels makes it highly vulnerable to international price fluctuations, and, as a landlocked nation, to foreign trade policy. Example of India blockade in 2015 can be taken as the major event and how it had affected the energy supply in Nepal.

c. Fossil fuels are valid for about three decades from now. As our whole system of transportation, cooking gas (especially in urban and suburbs) are based on the imported fossil fuels and the trend is increasing, shortage of fossil fuels in near future is going to hit hard on Nepal.

\subsection{Biogas as an alternative source}

\subsubsection{Potential of biogas}

Nepal is going through a huge change through geopolitical scenario, where it is divided into provinces and power is decentralized in the local level. So, each of the rural areas is turning into municipality and suburbs are developing into urban areas. Population density and sprawls are likely to increase in regional growth centers of provinces.

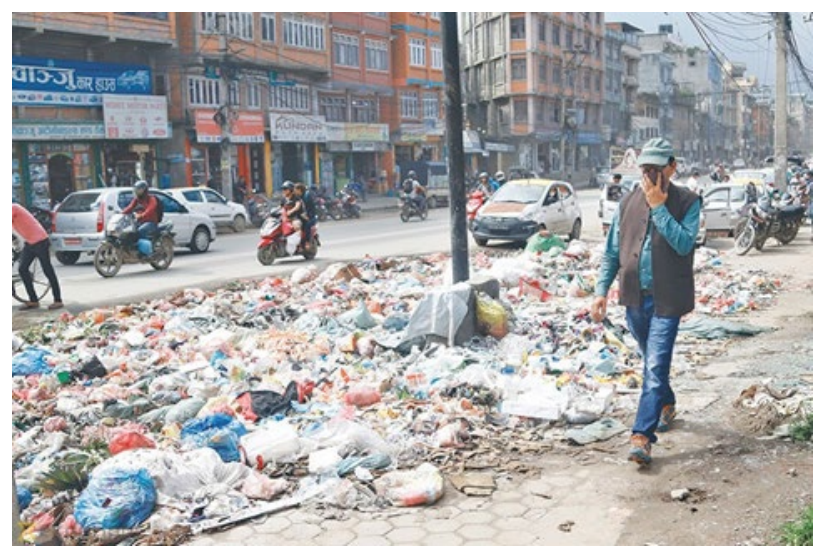

Figure 10: Waste on roads of Kathmandu

Along with the increase in population, there is increase in the problem of solid waste management. Presently, Kathmandu valley alone produces about 500 tons of solid waste per day and it is disposed in landfills of Sisdole site at Nuwakot. The site is the largest one, but is unable to cope with the growing waste as well as rising social and environmental issues. Due to this, Kathmandu is looking for an alternative as Bancharedanda with an area of 1,782 ropanis, which will be the largest landfill site in coming years. About $10 \%$ of the total municipal budget is spent on solid waste management [13]. This is more or less in line with findings of another study undertaken under the TA for nine relatively large municipalities, which indicated that the SWM expenditures accounted for $16 \%$ of the total municipal expenditure. The municipality spends nearly $60 \%-70 \%$ of the total SWM budget on collection and street sweeping, $20 \%-30 \%$ on transport, and the rest on final disposal. These figures show the need 
for reducing collection and street sweeping costs through more efficient management, and allocating more for safe and effective final disposal [14].

A biogas plant that was initiated by Kathmandu metropolitan city by utilizing vegetable products to produce electricity is not on running phase now due to managerial issues.

Table 3: Amount of solid waste generated [14]

\begin{tabular}{|l|l|l|}
\hline S No. & Source of solid waste & $\begin{array}{l}\text { Amount of solid } \\
\text { waste/capita/day }\end{array}$ \\
\hline 1 & Households & $497.3 \mathrm{gm}$ \\
\hline 2 & Restaurants & $48.5 \mathrm{~kg}$ \\
\hline 3 & Hotels & $113.3 \mathrm{~kg}$ \\
\hline 4 & Schools & $26.1 \mathrm{~kg}$ \\
\hline
\end{tabular}

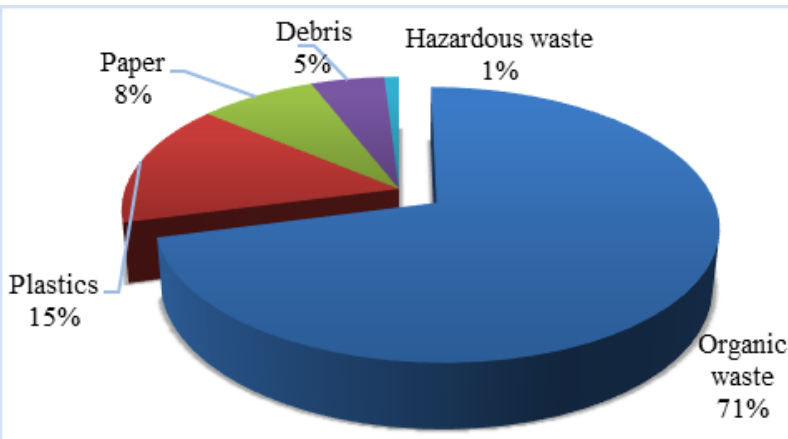

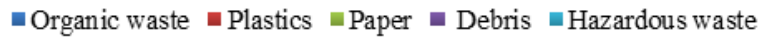

Figure 11: Percentage of constituents of household in Kathmandu (Province 3)

A study done based on Kathmandu metropolitan city has found that $497.3 \mathrm{~g} / \mathrm{capita} /$ day of solid waste are generated from households and 48.5, 113.3 and $26.1 \mathrm{~kg} /$ facility/day of waste was generated from restaurants, hotels and schools respectively. Street litter measured 69.3 metric tons/day; the average municipal solid waste generation rate was 523.8 metric tons/day or $0.66 \mathrm{~kg} / \mathrm{capita} /$ day. The coefficient of correlation between the number of people and the amount of waste produced was 0.94 [15].

Key household waste constituents included $71 \%$ organic wastes, $15 \%$ plastics, $8 \%$ paper and paper products, $5 \%$ dirt and construction debris and $1 \%$ hazardous wastes [15]. Although the waste composition varied depending on the source, the composition analysis of waste from restaurants, hotels, schools and streets showed a high percentage of organic wastes. These numbers suggest a greater potential for recovery of organic wastes via composting and there is an opportunity for recycling.
The rate of household waste generation in Gorkha municipality is found to be $0.24 \mathrm{~kg} / \mathrm{capita} / \mathrm{day}$ and estimated total household waste generation of 9.4tonnes/day. [15]

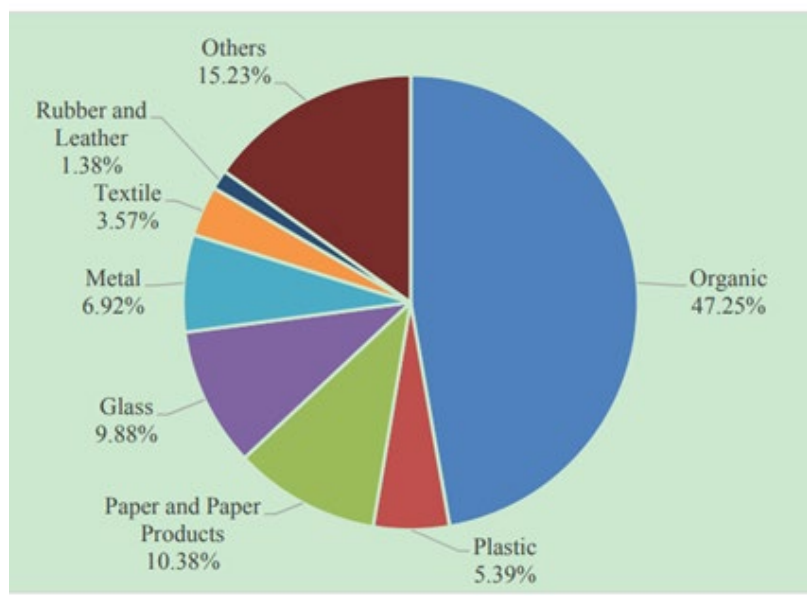

Figure 12: Percentage of constituents of household in Gorkha (Province 4)

Presently there are 6 metropolitan cities, 11 submetropolitan city, 293 urban municipalities and 460 rural municipalities in Nepal. The minimum population criteria are 300,000 for a metropolitan city, 150,000 for a submetropolitan and 60,000 for a municipality. Organic waste. More than half of the waste generated were seen to be bio-degradable waste, which has the potential to be used for production of biogas energy. The number of populations is also the base for the efficient and sustainable bio-gas energy, as the bio degradable waste generation is more with increasing population in urban areas.

\subsubsection{Advantage of biogas over other sources}

1. The biogas can be produced out of the waste found in local level.

2. The biogas is safer than LPG. LPG gas is 1.5 times heavier than air. So, when it leaks in surrounding, it remains in the ground level. But, Bio-methane is lighter than the air. So, it goes up in the atmosphere in case of leakage.

3. Biogas produced is odorless and also considered as clean gas.

4. Biogas is renewable source of energy.

5. It makes the community self-dependent.

6. It is best out of the waste.

7. It has got social and economic benefit.

8. It discourages dependency on fossil fuels.

9. It reduces carbon emission and is environment friendly. 


\section{Recommendation and Conclusion}

Nepal has gone through federal system of government where development is decentralized in local level. With increasing population density in growing municipalities and metropolitan cities, leads to increase the solid waste as well as energy demand. Presently, about $60 \%$ of the urban populations are residing in Nepal [16] and it is likely to increase in coming days. This fact can be taken as a source of motivation to actually manage those solid wastes and turn them into biogas for energy usage.

Following steps needs to be considered in order to bring the best out of waste:

a. Local government of each municipality and metropolitan city needs to make effective policy in order to promote biogas as an alternative source of energy.

b. Solid waste needs to be segregated from the source itself like households and institutional level into organic waste, reusable and recyclable waste. Awareness need to be made to general public regarding the segregation of waste in primary level.

c. Public private partnership need to be promoted rather than only governmental management of biogas, which will ultimately help in increasing efficiency and credibility.

d. Biogas thus produced can be supplied in cylinders or through pipelines in for cooking purpose in household and institutional level.

e. As municipal waste has high capacity of biogas yield per ton of waste, it can be the best way to manage waste as well as generate energy.

f. New municipalities which have infrastructures yet to be developed can take steps in sewage water treatment system into their agenda of development. This will certainly help in waste management as well as utilization in production of biogas.

g. Investments need to be done on research and invention of new technology supporting biogas. More of the biogas plants need to be promoted in growing municipalities such as at Ramgram municipality of Nepal.

Every growing urban area need to mainstream biogas technology in their local level with a policy to manage municipal solid waste. Sewage water treatment plant also needs to be encouraged to be included in their development agendas in every municipality. This will ultimately assist managing growing waste; create energy for heating, cooking and bio fuels for vehicles, which also has a lot of socio-economic and environmental benefits.
The possibility of biogas energy as an alternative source needs to be researched, understood, analyzed and included into development agenda. The system and working mechanism must slowly be inclined towards the renewable energy, for a sustainable future.

\section{Acknowledgments}

The author is thankful to all the interviewees for providing valuable information and scholars whose papers and articles have been of great help in preparation of this paper.

\section{References}

[1] K. Das, G. Pradhan and S. Nonhebel, "Human energy and time spent by women using cooking energy systems: A case study of Nepal," Energy, pp. 493-501, 2019.

[2] S. Zafar, "Raw material for bio gas plant," Bio energy consult, 27 november 2019. [Online]. Available: https:/www.bioenergyconsult.com/tag/raw-material-forbiogas-plants/. [Accessed $16 \mathrm{dec} 2019$ ].

[3] T. A. Seadi, D. Rutz, H. Prassl, M. Köttner, T. Finsterwalder, S. Volk and R. Janssen, Bio gas Hand book, University of Southern Denmark Esbjerg, 2008.

[4] "energypedia," 2010. [Online]. Available: https://energypedia.info/wiki/Nepal_Energy_Situation. [Accessed 20 sept 2018].

[5] Biogas Action country profile, [Online]. Available: http://biogasaction.eu/sweden-country-profile/. [Accessed 20 Sept 2018].

[6] K. Engdhal, "Biogas policies, incentives and barriers," 2010.

[7] Nepal Biogas Promotion Association (NBPA), "Nepal Improved Biogas Plant -Technical design report," Nepal Biogas Promotion Association (NBPA), Kathmandu, 2015.

[8] A. Agrawal, Interviewee, Biogas energy production. [Interview]. 10 August 2018.

[9] World health organization, "Household energy database," 2010.

[10] Indira Shakya, "LPG: The Dream Energy for Nepalese Women," Center for rural technology Nepal .

[11] Nepal oil corporation limited, "Nepal oil corporation limited , import and sales," [Online]. Available: http://www.nepaloil.com.np/import-and-sales-22.html. [Accessed sept 2018].

[12] W. Bank, 2014.

[13] B. Tuladhar, Interviewee, Solid waste management in Kathmandu valley. [Interview]. 15 September 2018.

[14] Kathmandu Metropolitan city, 2017. [Online]. Available: http://www.kathmandu.gov.np/. [Accessed 2018]. 
[15] M. s. Bijan maskey, "Household waste generating factor and composition study for effective management in gorkha municpality of Nepal," Canadian journal of science and education , 2017.

[16] ekantipur, "42 percent population lives in urban centers: economic survey," May 28, 2018. 